\title{
Fingerprinting of Flavobacterium psychrophilum isolates by ribotyping and plasmid profiling
}

\author{
Chehid Chakroun ${ }^{1}$, Francine Grimont ${ }^{2}$, Maria C. Urdaci ${ }^{3}$, Jean-François Bernardet ${ }^{1, *}$ \\ ${ }^{1}$ Unité de Virologie et Immunologie Moléculaires, Institut National de la Recherche Agronomique, \\ F-78352 Jouy-en-Josas Cedex, France \\ ${ }^{2}$ Unité des Entérobactéries, Unité 389 de l'Institut National de la Santé et de la Recherche Médicale, Institut Pasteur, \\ F-75724 Paris Cedex 15, France \\ ${ }^{3}$ Laboratoire de Microbiologie, Ecole Nationale des Ingénieurs des Travaux Agricoles de Bordeaux, \\ 1 cours du Général de Gaulle, BP 201, F-33175 Gradignan Cedex, France
}

\begin{abstract}
Flavobacterium psychrophilum is the agent of cold-water disease and rainbow trout fry syndrome in salmonid fish worldwide. Ribosomal RNA gene restriction patterns (ribotypes) and plasmid profiles were determined on a collection of 85 strains isolated from different countries and fish species. Several ribotypes were obtained by using the restriction endonucleases Hinc II and PvuIl. Computer analysis of the ribotypes revealed that some of them were clearly associated with the fish species from which the strains were isolated, whereas no correlation with the geographical origin was found. Most of the strains harboured at least one plasmid and several different plasmid profiles were observed, even among strains sharing the same ribotype. These methods, used alone or in combination with other typing techniques, can be considered powerful tools for the epidemiological tracing of F. psychrophilum infections.
\end{abstract}

KEY WORDS: Flavobacterium psychrophilum - Cold-water disease Rainbow trout fry syndrome Ribotyping · Plasmid profiling · Epidemiology

\section{INTRODUCTION}

Flavobacterium psychrophilum (Bernardet et al. 1996) (syn. Cytophaga psychrophila, Flexibacter psychrophilus) is the causative agent of cold-water disease and rainbow trout fry syndrome in salmonid fish and is also occasionally isolated from non-salmonid fish (Chakroun et al. 1997, and references therein). Originally isolated in North America only, this pathogen now occurs in most countries in which salmonid fish farming is of economical importance, but the epidemiology of the disease is still poorly understood. Different typing techniques have been used to compare F. psychrophilum strains, such as serologic analysis (Lorenzen 1994, Wakabayashi et al. 1994), electrophoretic pattern of proteases (Bertolini et al. 1994), and random amplified polymorphic DNA (RAPD) (Chakroun et al. 1997). The latter study showed that no correlation occurred between RAPD profiles and the geographical origin of the strains, while some pro-

•Addressee for correspondence. E-mail: jfb@biotec.jouy.inra.fr files were clearly associated with the species of fish from which the strains were isolated. Ribosomal RNA gene restriction patterns (ribotypes) have been proposed by Grimont \& Grimont $(1986,1995)$ for differentiation of bacterial strains at infraspecific and infrasubspecific levels. In the present study, ribotypes, as well as plasmid profiles, were determined on a collection of $85 F$. psychrophilum strains isolated from different geographical areas and fish hosts over a long period of time in order to evaluate their potential for the epidemiological tracing of F. psychrophilum strains.

\section{MATERIALS AND METHODS}

Bacterial strains and growth conditions. The 85 Flavobacterium psychrophilum strains included in this study are listed in Table 1. This collection comprises strains retrieved from 13 countries (France, Switzerland, Norway, Germany, Sweden, Denmark, United Kingdom, Spain, Chile, the United States, Canada, 
Table 1. Flavobacterium psychrophilum strains included in this study

\begin{tabular}{|c|c|c|c|c|}
\hline \multirow{2}{*}{ Strain } & \multirow{2}{*}{ Origin } & \multirow{2}{*}{$\begin{array}{c}\text { Plasmid } \\
\text { content }(\mathrm{kb})\end{array}$} & \multicolumn{2}{|c|}{ Ribotypes } \\
\hline & & & Hinc II & Pvull \\
\hline JIP 02/86 & Rainbow trout Oncorhynchus mykiss kidney, Picardie, France, 1986 & $3.2,2.5$ & $\mathrm{H} 1$ & P1 \\
\hline JIP P02/88 & Rainbow trout, kidney, Picardie, France, 1988 & 3.5 & $\mathrm{H} 2 \mathrm{a}$ & P2a \\
\hline JIP $22 / 90$ & Rainbow trout, skin lesion, Nord-Pas-de-Calais, France, 1990 & 4.0 & $\mathrm{H} 3$ & P3 \\
\hline LVDL $5211 / 90$ & Rainbow trout, eye, Aquitaine, France, 1990 & 3.5 & $\mathrm{H} 4$ & P27 \\
\hline LVDL $1456 / 91$ & Rainbow trout, liver, Aquitaine, France, 1991 & 3.5 & H5 & P1 \\
\hline LVDJ E2047 & Rainbow trout, spleen, Jura, France, 1995 & 3.5 & $\mathrm{H} 1$ & P1 \\
\hline LPAA P01/88 & Rainbow trout, spleen, Brittany, France, 1988 & 3.5 & $\mathrm{H} 2 \mathrm{a}$ & $\mathrm{P} 2 \mathrm{~d}$ \\
\hline LPAA P03/88 & Rainbow trout, spleen, Brittany, France, 1988 & 3.5 & $\mathrm{H} 6$ & $\mathrm{P} 4$ \\
\hline LVDL $1829-91$ & Rainbow trout, liver, Navarra, Spain, 1991 & 3.5 & $\mathrm{H} 2 \mathrm{a}$ & $\mathrm{P} 2 \mathrm{a}$ \\
\hline LVDL $3077-91$ & Rainbow trout, spleen, Navarra, Spain, 1991 & 3.5 & $\mathrm{H7}$ & $\mathrm{P} 2 \mathrm{f}$ \\
\hline ISTAB AC $15 / 1.1$ & Rainbow trout, spleen, Navarra, Spain, 1996 & 3.5 & $\mathrm{H} 2 \mathrm{a}$ & $\mathrm{P} 2 \mathrm{a}$ \\
\hline SVA $31-88$ & Rainbow trout, muscle, Sweden, 1988 & 3.5 & $\mathrm{H} 2 \mathrm{a}$ & $\mathrm{P} 2 \mathrm{a}$ \\
\hline SVS $911209-1$ & Rainbow trout, spleen, Trehoje, Denmark, 1990 & 3.5 & $\mathrm{H} 2 \mathrm{a}$ & $\mathrm{P} 2 \mathrm{a}$ \\
\hline SVS $911209-2$ & Rainbow trout, spleen, Brons, Denmark, 1990 & 3.5 & $\mathrm{H} 2 \mathrm{a}$ & P2a \\
\hline SVS $910516-1$ & Rainbow trout, spleen, Spjarup, Denmark, 1991 & 0 & $\mathrm{H} 8$ & P5 \\
\hline SVS $910611-1$ & Rainbow trout, spleen, Løvlund, Denmark, 1991 & $3.5,3.0$ & $\mathrm{H} 8$ & P6 \\
\hline SVS $911009-3$ & Rainbow trout, skin lesion, Rindsholm, Denmark, 1991 & 3.5 & $\mathrm{H} 2 \mathrm{a}$ & $\mathrm{P} 2 \mathrm{a}$ \\
\hline SVS $911126-3$ & Rainbow trout, skin lesion, Bregnholm, Denmark, 1991 & 3.5 & $\mathrm{H} 2 \mathrm{a}$ & $\mathrm{P} 2 \mathrm{a}$ \\
\hline SVS $930210-1$ & Rainbow trout, eye, Denmark, 1993 & $3.5,3.0$ & H9 & P7 \\
\hline SVS $930305-1$ & Rainbow trout, kidney, Denmark, 1993 & $3.5,3.0$ & $\mathrm{H} 10$ & P8 \\
\hline SVS $930310-1$ & Rainbow trout, spleen, Denmark, 1993 & 3.5 & $\mathrm{H} 2 \mathrm{a}$ & P2a \\
\hline DIFR $8804061 / 7$ & Rainbow trout, kidney, Denmark, 1990 & 3.5 & $\mathrm{H} 2 \mathrm{a}$ & $\mathrm{P} 2 \mathrm{a}$ \\
\hline DIFR $9004061 / 2$ & Rainbow trout, kidney, Denmark, 1990 & 3.5 & $\mathrm{H} 2 \mathrm{a}$ & $\mathrm{P} 2 \mathrm{a}$ \\
\hline DIFR $9508241 / 1$ & Rainbow trout, spleen, Denmark, 1996 & 3.5 & $\mathrm{H} 2 \mathrm{a}$ & P2a \\
\hline DIFR $9509201 / 1$ & Rainbow trout, spleen, Denmark, 1996 & 3.5 & $\mathrm{H} 2 \mathrm{a}$ & $\mathrm{P} 2 \mathrm{a}$ \\
\hline LFNW 123/89 & Rainbow trout, skin lesion, Nordrhein-Westfalen, Germany, 1989 & 0 & H11 & $\mathrm{P9a}$ \\
\hline IVP CH1/93 & Rainbow trout, Berne, Switzerland, 1993 & 3.5 & $\mathrm{H} 2 \mathrm{a}$ & $\mathrm{P} 2 \mathrm{a}$ \\
\hline IVP CH4/93 & Rainbow trout, spleen, Berne, Switzerland, 1993 & 0 & $\mathrm{H} 12$ & P10 \\
\hline IVP CH7/93 & Rainbow trout, Berne, Switzerland, 1993 & 3.5 & $\mathrm{H} 2 \mathrm{a}$ & P2a \\
\hline IVP CH8/93 & Rainbow trout, spleen, Fribourg, Switzerland, 1993 & 3.5 & $\mathrm{H} 13$ & P11 \\
\hline IVP CH3/94 & Rainbow trout, spleen, Vaud, Switzerland, 1994 & 3.5 & H14 & $\mathrm{P} 2 \mathrm{C}$ \\
\hline MLA MT 1368 & Rainbow trout, kidney, Borders, United Kingdom, 1993 & 3.5 & $\mathrm{H} 2 \mathrm{a}$ & $\mathrm{P} 2 \mathrm{a}$ \\
\hline CVLO $730 / 96-1$ & Rainbow trout, kidney, Oslo, Norway, 1996 & 0 & $\mathrm{H} 15$ & $\mathrm{P} 12$ \\
\hline OSU BFRbG3-84 & Rainbow trout, gills, Oregon, USA, 1984 & 0 & $\mathrm{H} 16 \mathrm{a}$ & P24 \\
\hline OSU KHRb2-85 & Rainbow trout, peduncle lesion, Oregon, USA, 1985 & 0 & H17 & P14 \\
\hline OSU WFRB2-90 & Rainbow trout, kidney, Idaho, USA, 1990 & 3.5 & $\mathrm{H} 16 \mathrm{c}$ & P13 \\
\hline OSU $90-66 \mathrm{~A}$ & Rainbow trout, spleen, Idaho, USA, 1990 & 3.5 & $\mathrm{H} 7$ & $\mathrm{P} 2 \mathrm{a}$ \\
\hline OSU Ana 9.1 .1 & Rainbow trout, kidney, Oregon, USA, 1991 & 3.5 & $\mathrm{H} 7$ & P2a \\
\hline UCD 004-95 & Rainbow trout, kidney, Idaho, USA, 1995 & 3.5 & $\mathrm{H} 7$ & $\mathrm{P} 2 \mathrm{e}$ \\
\hline UCD 95.7 & Rainbow trout, kidney, California, USA, 1995 & 3.5 & $\mathrm{H} 7$ & P2a \\
\hline UCD 146-95 & Rainbow trout, kidney, Idaho, USA, 1995 & 3.5 & $\mathrm{H} 7$ & P2a \\
\hline UCD R3/8/95 & Rainbow trout, USA, 1995 & 3.0 & $\mathrm{H} 2 \mathrm{a}$ & $\mathrm{P} 2 \mathrm{a}$ \\
\hline FC $1285-96$ & Rainbow trout, spleen, Chile, 1996 & 3.5 & $\mathrm{H} 2 \mathrm{a}$ & $\mathrm{P} 2 \mathrm{a}$ \\
\hline FPC 813 & Rainbow trout, kidney, Tokyo, Japan, 1992 & 3.5 & $\mathrm{H} 2 \mathrm{a}$ & $\mathrm{P} 2 \mathrm{~b}$ \\
\hline OSU RbS6-82 & Steelhead trout O. mykiss, kidney, Oregon, USA, 1982 & 3.5 & H18 & P15 \\
\hline OSU CCC $6-86$ & Cutthroat trout Salmo clarki, Oregon, USA, 1986 & 3.5 & H19 & P16 \\
\hline NCIMB $1947^{\top}$ & Coho salmon Oncorhynchus kisutch, kidney, Washington, USA & 2.7 & $\mathrm{H} 20$ & P17 \\
\hline NCIMB 2282 & Coho salmon, kidney, Washington, USA, 1948 & 0 & $\mathrm{H} 20$ & P17 \\
\hline OSU SH3-81 & Coho salmon, kidney, Oregon, USA, 1981 & 2.7 & $\mathrm{H} 21$ & P18 \\
\hline OSU PCP1.1 & Coho salmon, kidney, Oregon, USA, 1989 & 0 & $\mathrm{H} 21$ & P18 \\
\hline OSU TM3.1 & Coho salmon, kidney, Oregon, USA, 1989 & 0 & $\mathrm{H} 22$ & P19 \\
\hline OSU THCO2-90 & Coho salmon, kidney, Oregon, USA, 1990 & 0 & $\mathrm{H} 21$ & P18 \\
\hline OSU THCO $4-90$ & Coho salmon, kidney, Oregon, USA, 1990 & 0 & $\mathrm{H} 21$ & P18 \\
\hline OSU SRCo5-90 & Coho salmon, kidney, Oregon, USA, 1990 & 0 & $\mathrm{H} 21$ & P18 \\
\hline OSU NHCO4-90 & Coho salmon, kidney, Oregon, USA, 1990 & 3.0 & $\mathrm{H} 19$ & P16 \\
\hline OSU NHCO2-90 & Coho salmon, kidney, Oregon, USA, 1990 & 3.0 & $\mathrm{H} 19$ & P16 \\
\hline OSU CO26.BR.2.1 & Coho salmon, brain, Oregon, USA, 1990 & 0 & $\mathrm{H} 21$ & P18 \\
\hline OSU BC $3-81$ & Coho salmon, kidney, Oregon, USA, 1981 & $3.2,2.5$ & $\mathrm{H} 19$ & P16 \\
\hline OSU Ch8-80 & Coho salmon, Oregon, USA, 1980 & 0 & H19 & P16 \\
\hline OSU $84-254$ & Coho salmon, skin lesion, British Columbia, Canada, 1984 & 3.5 & $\mathrm{H} 23$ & $\mathrm{P} 20$ \\
\hline FC $777-96$ & Coho salmon, kidney, Chile, 1996 & 0 & $\mathrm{H} 21$ & P18 \\
\hline FC $799-96$ & Coho salmon, kidney, Chile, 1996 & 0 & $\mathrm{H} 21$ & P18 \\
\hline FC $807-96$ & Coho salmon, spleen, Chile, 1996 & 0 & $\mathrm{H} 21$ & P18 \\
\hline FPC 828 & Coho salmon, kidney, Miyagi, Japan, 1990 & 2.7 & $\mathrm{H} 24$ & P18 \\
\hline
\end{tabular}


Table 1 (continued)

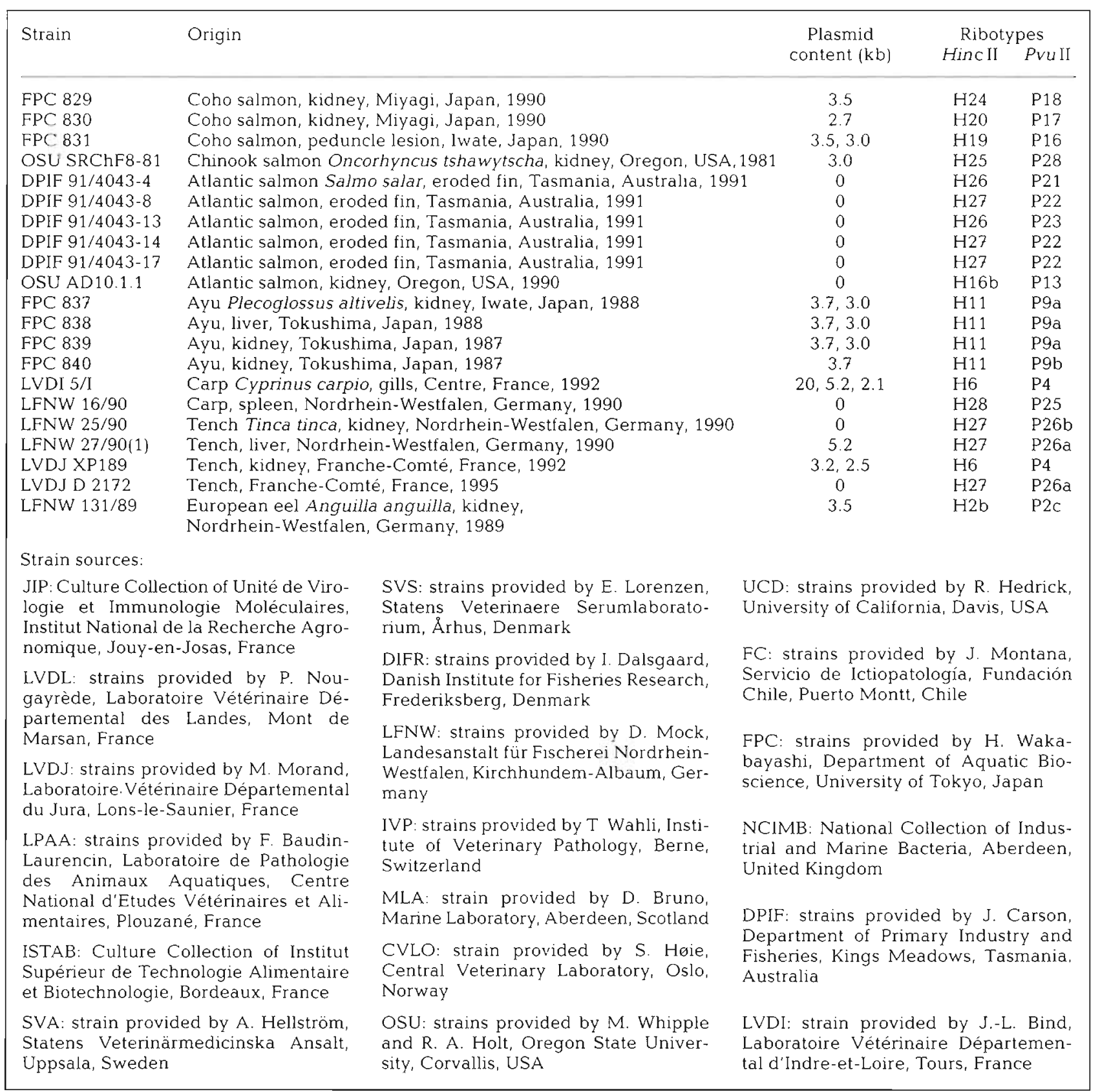

Australia, and Japan) and 10 different fish species (rainbow, steelhead, and cutthroat trouts, coho, chinook, and Atlantic salmons, ayu, carp, tench, and European eel). All strains were grown at $18^{\circ} \mathrm{C}$ on Anacker and Ordal medium (Anacker \& Ordal 1955) supplemented with $0.45 \%$ of tryptone. The supplemented broth contained $0.5 \%$ tryptone, $0.05 \%$ yeast extract, $0.02 \%$ beef extract, $0.02 \%$ sodium acetate, $\mathrm{pH}$ 7.2 to 7.4 , and the corresponding solid medium was obtained by adding $1 \%$ agar. All strains had previously been identified according to phenotypical characteris- tics as described by Pacha (1968), Bullock (1972), and Bernardet \& Kerouault (1989).

DNA extraction. Flavobacterium psychrophilum colonies were collected on agar plates, suspended in $0.9 \%$ saline and centrifuged, and the DNA was extracted and purified following published methods (Chakroun et al. 1997). The concentration of the DNAs was evaluated after agarose gel electrophoresis of $1 \mu \mathrm{l}$ samples, and all DNA solutions were adjusted with sterile Milli- $Q$ water so that restriction could be performed on the same amount of DNA. 
Ribotyping. Ribotyping was performed as described by Regnault et al. (1997). The DNA from the Flavobacterium psychrophilum strains NCIMB $1947^{\mathrm{T}}$ and FPC 839 was first tested for restriction with the following 23 restriction endonucleases: $A C c$ I, $A l u$ I, $B a m H$ I, $B g l$ I, BglII, BstE II, ClaI, DdeI, Dra I, EcoR I, EcoR V, Hha I, Hinc II, Hind III, KpnI, MluI, PstI, PvuII, SacI, SalI, SmaI, RsaI, and Xhol. Bacterial DNAs (3 to $5 \mu \mathrm{g}$ ) were cleaved by restriction endonucleases following the supplier's instructions (Amersham International, Amersham, UK). All 85 strains were then cleaved by Hinc II and Pvu II. Restriction fragments were separated by low-voltage $\left(1.5 \mathrm{~V} \mathrm{~cm}^{-1}\right)$ electrophoresis for $16 \mathrm{~h}$ on $0.8 \%$ agarose (Appligène, lllkrich, France) gel in Tris-borate buffer $(89 \mathrm{mM}$ Tris-base, $89 \mathrm{mM}$ boric acid, 2 mM disodium EDTA, pH 8.3) (Maniatis et al. 1982). The DNA of Citrobacter koseri CIP 105177 cleaved by MluI was used as the molecular size marker in 3 lanes in each 20 lane gel. DNA fragments were then transferred to a nylon membrane (Hybond $\mathrm{N}+$, Amersham) using a VacuGene system (Pharmacia LKB Biotechnology, Uppsala, Sweden) as described by Grimont \& Grimont (1995) without the depurination step. Hybridization was performed at $52^{\circ} \mathrm{C}$ using as a probe 5 synthetic oligonucleotides (100 pmol of each) produced by Genset (Paris, France) (Regnault et al. 1997) and labeled by digoxigenin-dUTP/dATP following the supplier's instructions (DIG Oligonucleotide Tailing Kit, Boehringer Mannheim, Meylan, France). These oligonucleotides were complementary to 2 gene regions on the $16 \mathrm{~S}$ rRNA and 3 gene regions on the $23 \mathrm{~S}$ rRNA of Escherichia coli. Probes were detected by using an alkaline phosphatase-conjugated anti-digoxigenin antibody. Ribotypes were revealed using $\mathrm{X}$ phosphate (5-bromo-4-chloro-3-indolyl-phosphate) and Nitro-Blue-Tetrazolium (DIG Nucleic Acid Detection Kit, Boehringer).

Computer-assisted analysis of ribotypes. Ribotyping banding patterns were scanned with a laser densitometer (One-Scanner, Apple Computers, Cupertino, CA) and analyzed by using various programs of the Taxotron ${ }^{(3)}$ package (Taxolab, Institut Pasteur, France). The TIFF image was searched for lanes and bands using RestrictoScan yielding migration data. Fragments sizes were interpolated from migration data using RestrictoTyper implementing the algorithm of Schaffer \& Sederoff (1981). RestrictoTyper compared pairs of patterns and calculated a distance coefficient which was the complement of the Dice index. We chose to set a fixed value of $5 \%$, indicating that 2 fragments were considered identical if their sizes did not differ by more than $5 \%$. A distance matrix was generated for the patterns obtained with each of the restriction enzymes Hinc II and PvuII. These distance matrices were averaged using the program Adanson and treated by the average linkage algorithm of Bartelemy \& Guénoche (1988). The program, which is insensitive to the order of strains in the distance matrix, generated a tree description file which was used by the program Dendrograf to draw a dendrogram and produce an order file. The order file was used by RestrictoTyper to reorder the fragment sizes files and produce a schematic representation of the patterns. The dendrogram and the schematic graph were assembled in a single picture by using the drawing program Claris Works (Claris Corporation, Santa Clara, CA).

Plasmid profiling. Plasmid profiles were determined as described by Takahashi \& Nagano (1984). Briefly, $4 \mathrm{ml}$ of a $72 \mathrm{~h}$ Anacker \& Ordal (1955) broth culture were centrifuged at $5000 \times g$ for $10 \mathrm{mn}$. The pellet was suspended in $200 \mu \mathrm{l}$ of TE $(40 \mathrm{mM}$ Tris buffer, $2 \mathrm{mM}$ EDTA, pH 8.0) and bacterial cells were lysed by adding $400 \mu \mathrm{l}$ of an extemporaneously prepared solution containing $0.5 \mathrm{M}$ Tris buffer, $2 \%$ sodium dodecyl sulphate (SDS) and $0.2 \mathrm{~N} \mathrm{NaOH}$. The mixture was neutralized by adding $300 \mu \mathrm{l}$ of $3 \mathrm{M}$ sodium acetate and treated twice by an equal volume of phenol. The supernatant was precipitated by adding $1 \mathrm{ml}$ of precooled ethanol $\left(-20^{\circ} \mathrm{C}\right)$. The precipitate was suspended into $50 \mu \mathrm{l}$ of sterile Milli-Q water containing $10 \mu \mathrm{g}$ of RNase (ribonuclease I-A from bovine pancreas, Sigma Chemical Co., St. Louis, MO) and incubated at $37^{\circ} \mathrm{C}$ for $15 \mathrm{~min}$. Samples $(50 \mu \mathrm{l})$ from all tubes were electrophoresed in a $0.8 \%$ agarose gel in Tris-borate buffer (89 mM Tris base, $89 \mathrm{mM}$ boric acid, $2 \mathrm{mM}$ EDTA) for $5 \mathrm{~h}$ at $2 \mathrm{~V} \mathrm{~cm}^{-1}$. The supercoiled DNA ladder (Gibco BRL, Life Technologies, Cergy Pontoise, France) was used as molecular weight marker. Plasmids were visualized after ethidium bromide staining on a UV light transilluminator and photographed.

\section{RESULTS}

\section{Ribotyping}

Among the 23 restriction endonucleases screened, Hinc II and PvuII were selected for further analysis of all strains because they generated the most interesting profiles regarding the number, diversity, and distribution of the bands and because these profiles provided the best differentiation between the 2 Flavobacterium psychrophilum strains tested (data not shown). Some examples of ribotypes produced by Hinc Il are presented in Fig. 1. When the whole collection of strains was tested, Hinc II separated the $85 \mathrm{~F}$. psychrophilum strains into 28 ribogroups $(\mathrm{H} 1$ to $\mathrm{H} 28)$ and 31 ribotypes (for instance, the ribogroup $\mathrm{H} 16$ comprised the 3 ribotypes $\mathrm{a}, \mathrm{b}$, and $\mathrm{c}$ ), each grouping 1 to 20 strains, while 28 ribogroups ( $\mathrm{P} 1$ to $\mathrm{P} 28$ ) and 35 ribotypes were ob- 
tained when PvuII was used, each grouping 1 to 22 strains. All ribogroups and ribotypes generated by the 2 endonucleases are listed in Table 1 . The number of rRNA gene restriction fragments in each profile ranged from 8 to 13 for Hinc II and from 7 to 17 for PVuII.

The dendrogram shown in Fig. 2 was generated by the computer analysis of the schematic representations of the ribotypes obtained with Hinc II only. Those obtained with Pvu II were also included in the figure because they either confirmed the clustering yielded by Hinc II or made further differentiation within HincII ribotypes possible. Most rainbow trout isolates (31 of 44), whatever their geographical origin, were grouped within the main cluster located at the upper part of the dendrogram, together with 1 carp isolate and the only eel isolate in our collection. This cluster comprised 8 Hinc II ribotypes (i.e. H1, $\mathrm{H} 2 \mathrm{a}$ and $2 \mathrm{~b}, \mathrm{H} 7, \mathrm{H} 9, \mathrm{H} 14$, $\mathrm{H} 17$, and $\mathrm{H} 28$ ) and $10 \mathrm{Pvu}$ II ribotypes (i.e. P1, $P 2 a$ to $2 f, P 7, P 14$, and P25). The remaining 13 rainbow trout isolates formed small clusters or occupied isolated positions in the dendrogram. Nineteen strains among 21 isolated from coho salmon in the USA, Japan, and Chile were tightly clustered and displayed 4 HincII ribotypes (i.e. H19, H2O, H21, and $\mathrm{H} 24$ ) and 3 PvuII ribotypes (i. e. P16, P17, and P18). The strain isolated from cutthroat trout was also included in this cluster, while the strain retrieved from chinook salmon exhibited a unique profile and consequently occupied an isolated position in the dendrogram. The ribotype of the US Atlantic salmon isolate was similar to that of 2 strains isolated from rainbow trout in the same region, whereas all 5 Atlantic salmon isolates from Tasmania were grouped within a tight cluster together with 3 tench isolates and 1 rainbow trout isolate, all originating from Europe. The 4 strains isolated from ayu in Japan shared the same distinct ribotypes (H11, P9a and 9b), together with a rainbow trout isolate from Germany. Whereas the carp isolate LFNW 16/90 from Germany grouped within the main cluster of rainbow trout isolates, the strain LVDI 5/I, retrieved from a carp in France, grouped together with 2 other French strains, one from tench and the other from rainbow trout.

\section{Plasmid profiling}

Eleven different plasmid profiles, shown in Table 1 and in Fig. 2, occurred among the 85 Flavobacterium psychrophilum strains. These profiles were composed of no plasmid at all (profile no. 0), one $2.7 \mathrm{~kb}$ plasmid

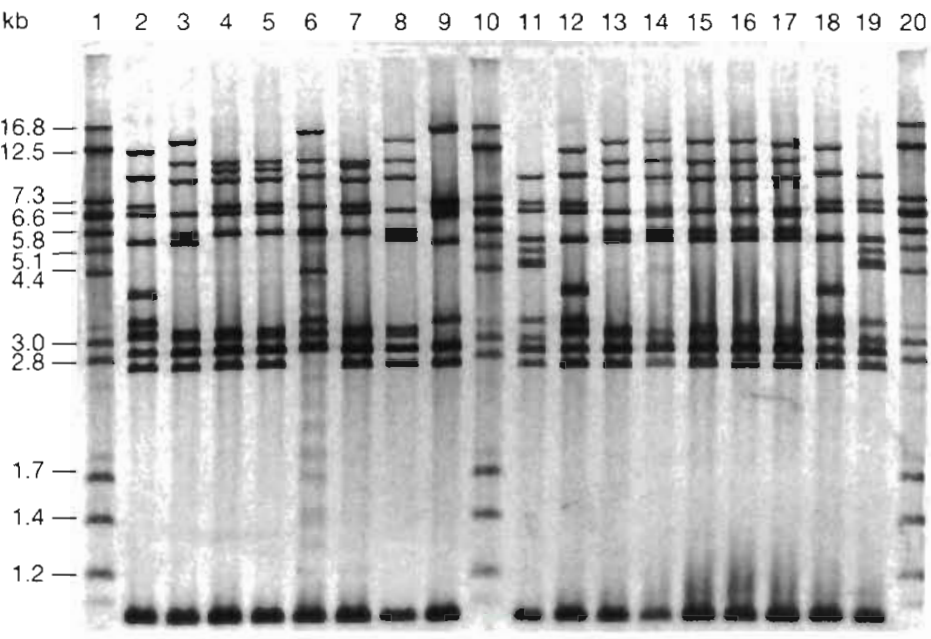

Fig. 1. Flavobacterium psychrophilum. Examples of ribotypes exhibited by some $F$. psychrophilum DNAs cleaved with endonuclease Hinc If Lanes: 2, ayu isolate FPC 840 (ribotype $\mathrm{H} 11$ ); 3, rainbow trout isolate UCD R3/8/95 (ribotype H2a); 4, rainbow trout isolate UCD 004/95 (ribotype $\mathrm{H7}$ ); 5, rainbow trout isolate OSU Ana 9.1.1 (ribotype $\mathrm{H} 7$ ); 6, coho almon isolate FPC 829 (ribotype $\mathrm{H} 24$ ); 7 , rainbow trout isolate UCD 146-95 (ribotype $\mathrm{H7}$ ); 8 , rainbow trout isolate JIP P02/88 (ribotype $\mathrm{H} 2 \mathrm{a}$ ) 9, steelhead trout isolate OSU RBS6-86 (ribotype $\mathrm{H} 18$ ); 11, tench isolate LVDJ 02172 (ribotype H27); 12, ayu isolate FPC 839 (ribotype H11); 13, rainbow trout isolate SVS 911209-2 (ribotype $\mathrm{H} 2 \mathrm{a}$ ); 14, rainbow trout isolate JIP 02/86 (ribotype H1); 15, rainbow trout isolate DIFR 900406 1/2 (ribotype H2a); 16 , rainbow trout isolate SVS $911209-1$ (ribotype H2a); 17, European eel isolate LFNW 131/89 (ribotype H2b); 18 , rainbow trout isolate LFNW 123/89 (ribotype H11); 19, tench isolate LFNW 25/90 (ribotype H27); 1, 10 and 20, molecular weight marker: ribotype of Citrobacter koseri CIP 105177 cleaved by Mlu I

(no. 1), one $3.0 \mathrm{~kb}$ plasmid (no. 2), one $3.5 \mathrm{~kb}$ plasmid (no. 3), one $3.7 \mathrm{~kb}$ plasmid (no. 4), one $4.0 \mathrm{~kb}$ plasmid (no. 5), one $5.2 \mathrm{~kb}$ plasmid (no. 6), 2 plasmids of 3.2 and $2.5 \mathrm{~kb}$ (no. 7), 2 plasmids of 3.5 and $3.0 \mathrm{~kb}$ (no. 8), 2 plasmids of 3.7 and $3.0 \mathrm{~kb}$ (no. 9), and 3 plasmids of 20 , 5.2 , and $2.1 \mathrm{~kb}$ (no. 10). Fifty-nine strains (69.4\%) harboured at least 1 plasmid. Thirty-seven strains (43.5\%) shared the same plasmid, whose relative molecular weight was estimated to be $3.5 \mathrm{~kb}$ (profile no. 3). Ten strains exhibited 2 plasmids (profiles nos. 7, 8, and 9) and the carp isolate LVDI 5/I also displayed a third plasmid of high molecular weight, estimated to be $20 \mathrm{~kb}$ (profile no. 10). Some isolates were tested several times because their profile showed some differences due to dimetric forms.

With 5 exceptions only, all strains included in the main cluster of the dendrogram (Fig. 2) (i.e. the cluster grouping most rainbow trout isolates as well as the strain retrieved from European eel and the German carp isolate) exhibited the same plasmid profile, harbouring only the $3.5 \mathrm{~kb}$ plasmid. The same plasmid was also found in a few strains not belonging to this cluster, i.e. 1 coho salmon isolate from Japan, 4 rainbow trout strains from France and Switzerland, 

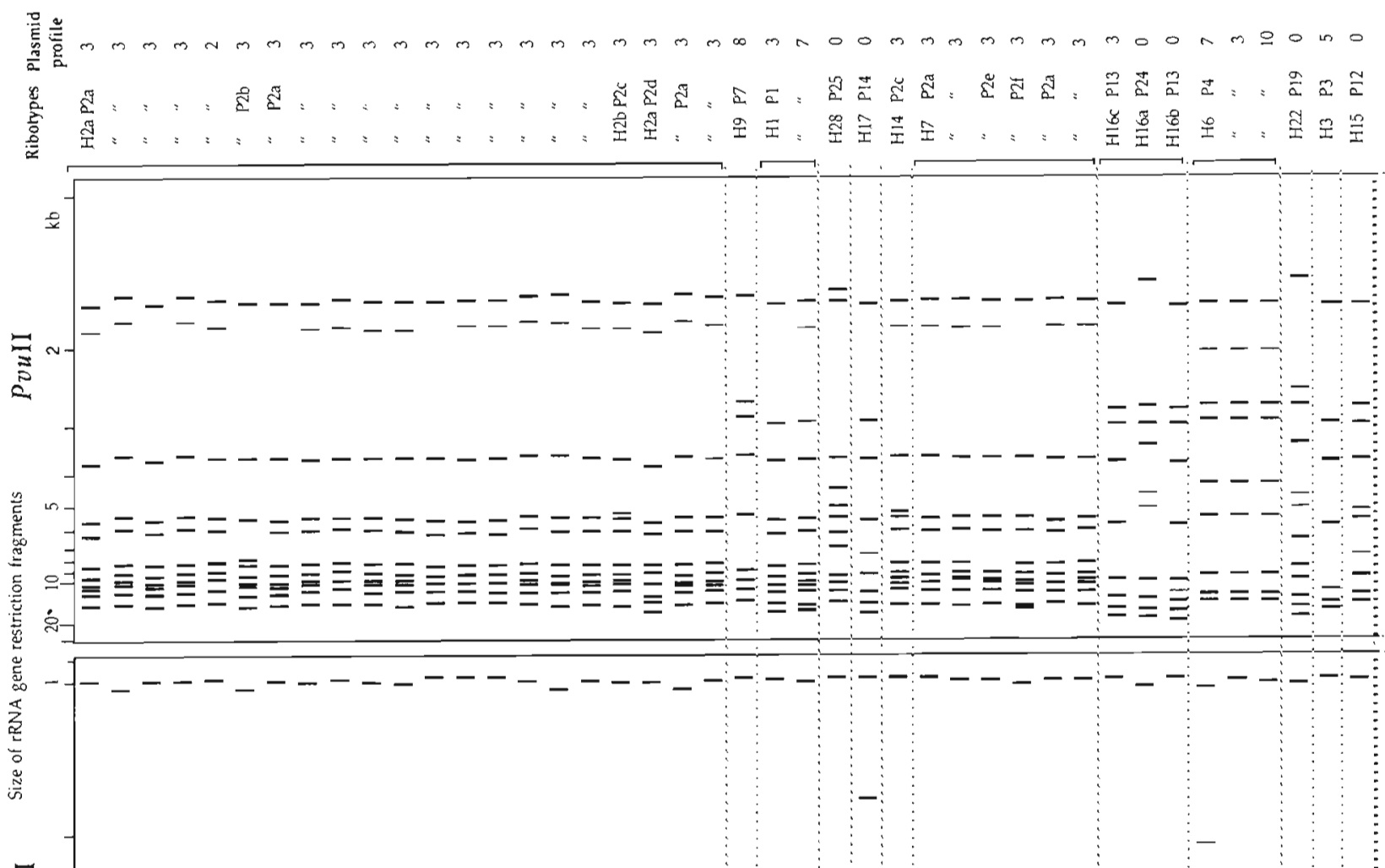

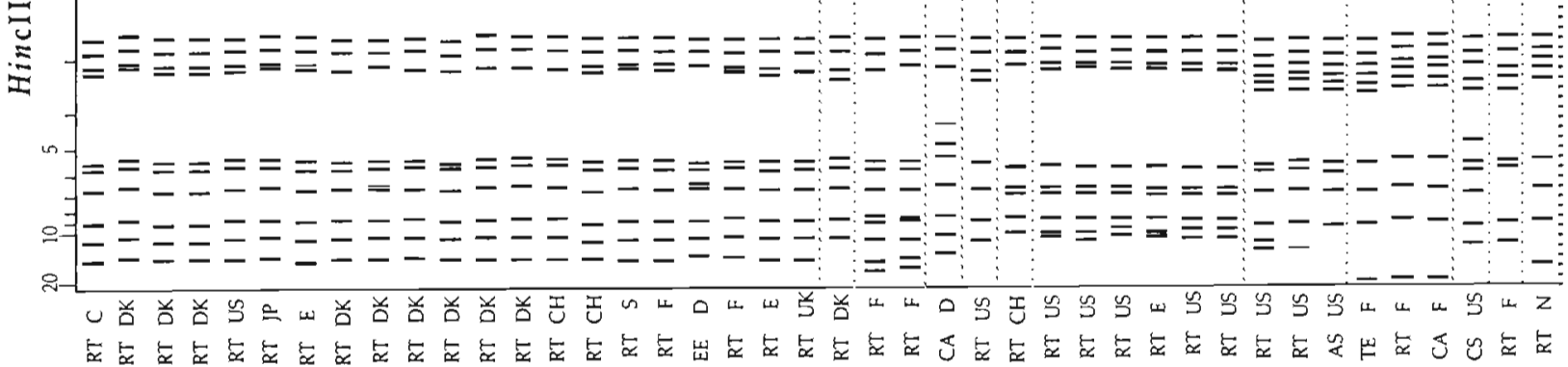
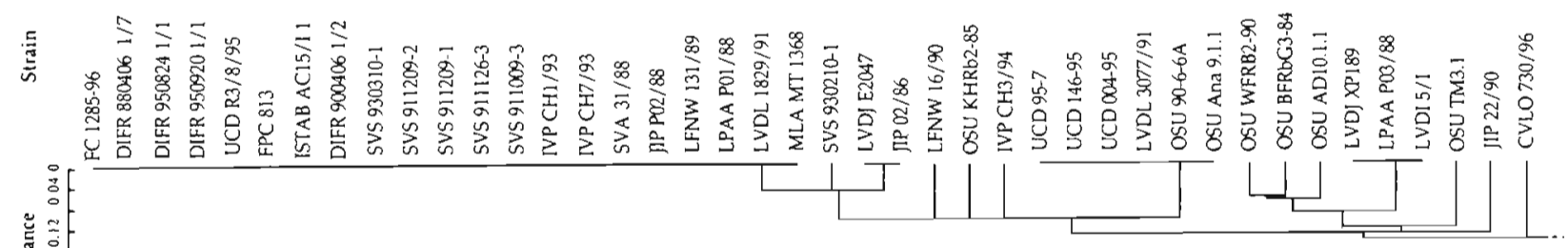

Fig. 2. Flavobacterium psychrophilum. Schematic representation of the ribotypes generated by the endonucleases Hinc II and Pvu II on 85 F. psychrophilum isolates and dendrogram established (from Hinc II ribotypes only) by Dendrograf, a computer program belonging to the Taxotron ${ }^{6}$ software package (Institut Pasteur, Paris), using the complement of Dice similarity coefficients. A fragment length tolerance of $5 \%$ and average linkage were used. Horizontal lines delimit the $28 \mathrm{Hinc}$ II ribogroups. Strain sources as in Table 1. RT: rainbow trout; EE: European eel; TE: tench; CA: carp: AS: Atlantic salmon; CS: coho salmon; CT: cutthroat trout; ChS: chinook salmon; ST: steelhead trout; A: ayu. F: France; S: Sweden; DK: Denmark; D: Germany; CH: Switzerland; E: Spain; US: USA; JP: Japan; C: Chile; N: Norway; UK: United Kingdom; AU: Australia

and 4 US strains isolated from coho salmon as well as rainbow, steelhead, and cutthroat trouts. All other strains displayed other plasmid profiles, and only limited correlations with fish host or geographical origin were noticed. For instance, the $2.7 \mathrm{~kb}$ plasmid was exclusively present in 4 US and Japanese coho salmon isolates (including the type strain), and the profile composed of the $3.0 \mathrm{~kb}$ plasmid alone was restricted to 4 US isolates from rainbow trout as well as coho and chinook salmons. The latter plasmid was also present, in combination with the $3.5 \mathrm{~kb}$ plasmid, in 3 strains retrieved from rainbow trout in Denmark 


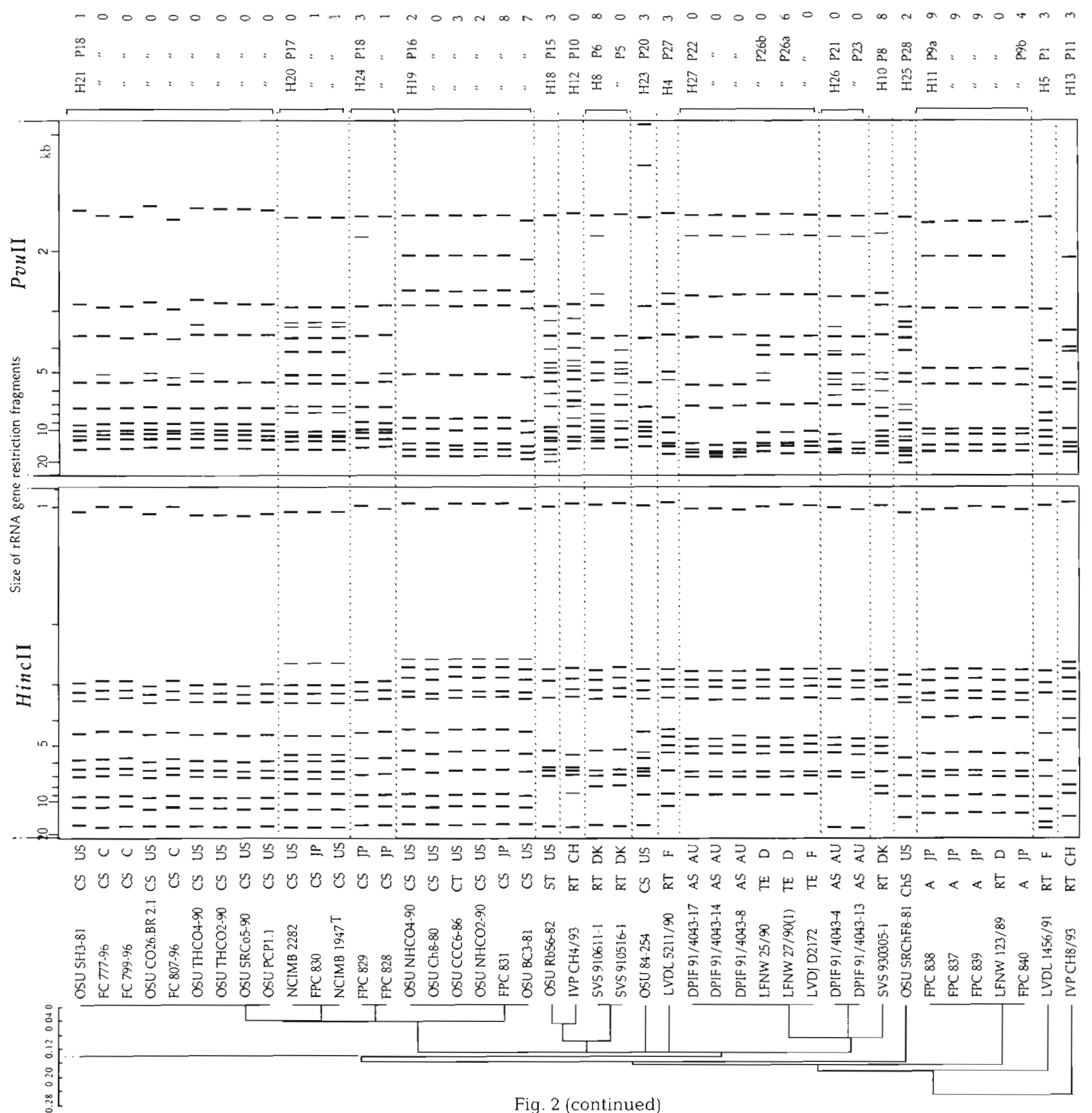

and 1 Japanese coho salmon isolate. A $3.7 \mathrm{~kb}$ plasmid characterized the 4 ayu isolates, combined with the $3.0 \mathrm{~kb}$ plasmid in 3 of them. Three strains only $(2$ French isolates from rainbow trout and tench, and 1 US strain from coho salmon) exhibited a profile composed of a 3.2 and a $2.5 \mathrm{~kb}$ plasmid. Twenty-six strains, isolated from different fish species and in various locations, harboured no plasmid at all. This was, for instance, the case for the 6 Atlantic salmon isolates.

\section{DISCUSSION}

In the only previously published work dealing with the ribotyping of Flavobacterium psychrophilum isolates, 3 restriction endonucleases were tested on 4 strains retrieved from different hatcheries (Cipriano et al. 1996). Each strain exhibited a different ribotype when EcoR I was used, suggesting that ribotyping could be used for studying the epidemiology of coldwater disease. In the present study, many different 
ribotypes were generated among the collection of 85 $F$. psychrophilum strains by the endonucleases Hinc II and PvuII, but the computer analysis of the schematic representations of Hinc II profiles revealed their overall homogeneity. The PvuII ribotypes usually confirmed the clustering of the strains resulting from the analysis of Hinc II ribotypes. On the whole, the results of ribotyping paralleled those recently obtained by RAPD on a collection of $177 \mathrm{~F}$. psychrophilum strains (Chakroun et al. 1997). However, the dendrogram resulting from the computer analysis of ribotypes in the present study (Fig. 2) was slightly more complicated than that resulting from the analysis performed with the same package on RAPD profiles. This was partly due to the fact that 25 more strains were included in the ribotyping study $(60$ strains were selected among the 177 for computer analysis of their RAPD profiles) and also to the fact that ribotyping proved more discriminatory than RAPD, yielding a higher number of different profiles when the same number of strains was tested. Because of the overall similarity between the results of these 2 typing techniques, many conclusions that were drawn from the RAPD study (Chakroun et al. 1997) may be extended to the present one.

The computer analysis revealed no correlation between the ribotypes and the geographical origin of the isolates, whereas some ribotypes were clearly associated with the fish species from which the strains were isolated. This correlation was not complete, however, as some profiles were shared by strains originating from different fish species. For instance, the isolate LFNW 131/89 from European eel grouped with most rainbow trout isolates, 3 strains from tench grouped with Atlantic salmon isolates, and 3 French strains from carp (LVDI 5/I), tench (LVDJ XP189), and rainbow trout (LPAA P03/88) shared identical ribotypes.

The strains originating from Japan represented 5 Hinc II ribotypes ( $\mathrm{H} 2 \mathrm{a}, \mathrm{H} 11, \mathrm{H} 19, \mathrm{H} 20$, and $\mathrm{H} 24)$ and 6 Prull ribotypes (P2b, P9a and 9b, P16, P17, and P18). The rainbow trout isolate as well as the 4 coho salmon isolates shared common profiles with the strains retrieved from the same fish hosts in other countries, whereas the 4 ayu isolates exhibited very characteristic profiles. As the RAPD study yielded a similar result, it seems likely that some Flavobacterium psychrophilum strains were introduced in Japan with infected trout and/or salmon eggs from the USA. The particular profiles generated by the 2 techniques for ayu isolates could result either from a modification of the imported strains after they passed to ayu or from local strains that preceded the introduction of 'exotic' strains and went unnoticed until ayu farming became intensive (Chakroun et al. 1997).

The Flavobacterium psychrophilum strains from Chile ( 1 from rainbow trout and 3 from coho salmon) also grouped with strains isolated from the same fish hosts in other countries (Fig. 2). All rainbow trout and salmon currently farmed in Chile result from various introductions. Chile first imported rainbow trout eggs from Germany, as well as Pacific salmon eggs, during the first quarter of the 20th century, and Atlantic salmon was introduced during the mid-eighties. Massive amounts of salmonid eggs are still imported each year: in 1996, approximately $52 \%$ of all eggs imported in Chile were rainbow trout eggs from the USA and Europe, $46 \%$ were Atlantic salmon eggs from Europe, and nearly $2 \%$ were coho salmon eggs from the USA (P. Bustos pers. comm.). It is thus likely that the F. psychrophilum strains isolated from Chilean rainbow trout and coho salmon originate from imported infected eggs of the corresponding fish species.

While the US Atlantic salmon isolate grouped with 2 rainbow trout strains also from the USA, the 5 strains retrieved in Tasmania from Atlantic salmon grouped within a different cluster. However, in spite of their overall similarity and although they were all isolated in 1991 in the same fish farm, their profiles could be differentiated by variations involving several rRNA gene restriction fragments. For instance, 2 fragments clearly differentiated the ribotype $\mathrm{H} 26$ exhibited by 2 strains from $\mathrm{H} 27$ exhibited by the 3 other strains (Fig. 2). Strains displaying different ribotypes may thus coexist in a very restricted area. The population of Atlantic salmon currently farmed in Tasmania has its origin in disease-free fish recently introduced from New South Wales, Australia, but previous attempts to establish breeding populations in Tasmanian rivers and lakes had taken place during the second half of the 19th century (Schmidtke \& Carson 1995). Atlantic salmon failed to develop, but the introduction of rainbow trout and brown trout from United Kingdom was successful. Therefore, although local Flavobacterium psychrophilum strains may have been naturally present in Tasmania before any importation of fish occurred, it is more likely that the pathogen was introduced from Europe. Indeed, the cluster grouping the Tasmanian Atlantic salmon isolates also comprised 3 strains isolated from tench in France and Germany and a rainbow trout isolate from Denmark, although these 4 strains could readily be distinguished from the Atlantic salmon isolates by their Pvu II ribotypes (Fig. 2).

More strains originating from Chile, Japan, and Australia should be studied for a better understanding of the relationship between DNA fingerprint and fish host, in particular strains retrieved from Atlantic salmon in Chile and rainbow trout in Tasmania. Importantly, although the present stock of farmed salmonids in Chile, Japan, and Australia mainly derives from European and/or American fish, there has been a 2 -way international trade in fish eggs and broodstocks 
for many years. For instance, French fish farmers have long relied on rainbow trout eggs imported from Australia when they needed to grow rainbow trout out of the local season for their reproduction. It is thus possible that some F. psychrophilum strains presently found in France actually originate from Australia.

Besides the above-mentioned example of Tasmanian Atlantic salmon isolates, the coexistence in a restricted area of Flavobacterium psychrophilum strains exhibiting different ribotypes was also demonstrated by those retrieved from several fish species during the same outbreak in a German river, i.e. the strains LFNW 131/89, LFNW 123/89, LFNW 16/90, and LFNW 25/90 from European eel, rainbow trout, carp, and tench, respectively. Similarly, the strains isolated from various salmonids in Oregon, USA, originated from several hatcheries relatively close to one another and between which extensive transfers of fish have occurred for many years, yet these strains exhibited rather different ribotypes. These data confirm those previously obtained by RAPD (Chakroun et al. 1997). Several strains of Vibrio anguillarum, each exhibiting a unique ribotype, were also isolated from the same hatchery (Pedersen \& Larsen 1993) and even from the same fish (Pedersen \& Larsen 1995).

Because the 60 Flavobacterium psychrophilum strains included in the computer analysis of their RAPD profiles (Chakroun et al, 1997) were all included in the present study, the correlation between the results of the 2 methods was readily apparent. In contrast, possible correlations between ribotyping and the other typing methods tested on F. psychrophilum [i.e. serologic analysis (Lorenzen 1994, Wakabayashi et al. 1994) and electrophoretic pattern of proteases (Bertolini et al. 1994)] were difficult to detect because only a few strains were included in some of these studies and fewer still belonged to our collection. For instance, a certain correlation between fish host and serotype was revealed by Wakabayashi's data, and the protease profile as well as the virulence of the strains were also partially associated with the fish host in Bertolini's work. These data and their relationship with RAPD profiles have been discussed elsewhere (Chakroun et al. 1997).

Ribotyping has been performed on several other fish pathogenic bacteria but no correlation with fish host was ever observed. The ribotypes generated among Vibrio vulnificus strains clearly differentiated biotypes 1 and 2 as well as US and Danish isolates (Høi et al. 1997). When a collection of fish pathogenic Vibrio spp. was analyzed by ribotyping, some endonucleases were able to differentiate Vibrio anguillarum from all other species (Austin et al. 1997). Other enzymes generated ribotypes that did not parallel the different biochemical profiles occurring among $V$. anguillarum serogroup O1 strains (Pedersen \& Larsen 1995), while the strains belonging to serogroup $\mathrm{O} 2$ were distinguished accord ing to their geographical origin (i.e. Northern versus Southern Europe) (Tiainen et al. 1995). Depending on the authors and on the endonuclease used, ribotyping of Aeromonas salmonicida subsp. salmonicida strains was either considered not discriminatory enough for epidemiological studies (Nielsen et al. 1994) or a valuable tool for differentiating strains according to their geographical origin (Hänninen et al. 1995).

Our collection of Flavobacterium psychrophilum strains displayed a rather large variety of extrachromosomal DNA. The only very clear correlation with ribotyping occurred for the main cluster of the dendrogram, grouping 31 rainbow trout isolates as well as 1 carp isolate and the only strain from European eel, as all of them (except 2 rainbow trout isolates) displayed the $3.5 \mathrm{~kb}$ plasmid (profile no. 3, Fig. 2). Moreover, 5 rainbow trout isolates not included in the main cluster also haboured the same plasmid. Previous investigations demonstrated that the presence of plasmid has no influence on RAPD profiles (Chakroun et al. 1997). This observation was extended to ribotypes by the present study, since strains displaying the same plasmid profile could belong to very different clusters in the dendrogram generated by computer analysis of their ribotypes. This is for instance the case for plasmid profile no. 3, displayed among others by the 2 most distantly related strains in the dendrogram. Conversely, the strains LVDI 5/I, LPAA P03/88, and LVDJ XP189 shared the same ribotypes although their plasmid contents were quite different (i.e. profile nos. 10, 3, and 7 , respectively). The cluster grouping most coho salmon isolates also comprised many different plasmid profiles (Fig. 2). Similar conclusions were drawn from investigations on Vibrio anguillarum, identical ribotypes being displayed by strains in which the virulence plasmid was present or absent (Pedersen \& Larsen 1995).

Several studies of Flavobacterium psychrophilum isolates already included the determination of their plasmid profiles. Eight of the 20 US and Canadian strains studied by Holt (1987) harboured 1 or 2 plasmids, and Pazos et al. (1993) found low molecular weight plasmids in 13 European strains. A small plasmid was also found in 69 of 70 Danish isolates as well as in 3 French reference strains (Dalsgaard 1993). The results of Lorenzen (1994) revealed 6 different plasmid profiles among $45 \mathrm{~F}$. psychrophilum isolates from Denmark and several other locations in Europe, 34 of them exhibiting the same plasmid whose relative molecular weight was estimated to be $3.7 \mathrm{~kb}$, and 7 strains containing no plasmid. Thirteen strains studied by Lorenzen were also included in our collection. On the whole, the 2 studies yielded congruent data, although slight differences in the estimation of the size of the plasmids occurred (e.g. 3.5 versus $3.7 \mathrm{~kb}$ for the major plasmid). 
The functions of the extrachromosomal DNA harboured by many Flavobacterium psychrophilum strains remain unknown. A relationship between the $3.7 \mathrm{~kb}$ plasmid and virulence was suggested because this plasmid was detected in all strains isolated from clinical outbreaks of rainbow trout fry syndrome and in none of those retrieved from fish exhibiting no classical signs of the disease (Lorenzen 1994). However, no clear correlation between virulence and plasmid content could be found when our data were compared with the protease groups defined by Bertolini et al. (1994). The very virulent strains composing Bertolini's group 1 displayed various plasmid profiles (i.e. profiles no. 0,1 , or 3 ), while the avirulent strains within groups 3 and 4 all harboured the $3.5 \mathrm{~kb}$ plasmid (profile no. 3 ).

In this study, 2 molecular typing methods were evaluated for addressing epidemiological questions concerning Flavobacterium psychrophilum. Ribotyping generated interesting epidemiological markers and proved even more discriminatory than RAPD for typing and tracing of the strains. In contrast, plasmid profiles were of limited value for epidemiological investigations but may provide further differentiation among strains exhibiting the same ribotypes and RAPD patterns.

Acknowledgements. The authors are indebted to the individuals who kindly provided bacterial strains. Helpful information about the history of salmonid importation in Chile were kindly provided by P. Bustos (Fundación Chile, Castro, Chile). $\mathrm{C}$. C. is grateful to S. Delautre and B. Regnault (Institut Pasteur, Paris) for kind advice and help with ribotyping. C.C. thanks the French Ministry of Foreign Affairs for a research grant.

\section{LITERATURE CITED}

Anacker RL, Ordal EJ (1955) Study of a bacteriophage infecting the myxobacterium Chondrococcus columnaris. J Bacteriol 70:738-741

Austin B, Austin DA, Blanch AR, Cerda M, Grimont F, Grimont PAD, Jofre J, Koblavi S, Larsen JL. Pedersen $K$, Tiainen $T$, Verdonck $L$, Swings $J$ (1997) A comparison of methods for the typing of fish-pathogenic Vibrio spp. Syst Appl Microbiol 20:89-101

Bartelemy JP, Guénoche A (1988) Les arbres et les représentations des proximités. Masson, Paris

Bernardet JF, Kerouault B (1989) Phenotypic and genomic studies of Cytophaga psychrophila isolated from diseased rainbow trout (Oncorhynchus mykiss) in France. Appl Environ Microbiol 55:1796-1800

Bernardet JF, Segers P, Vancanneyt M, Berthe F, Kersters K, Vandamme P (1996) Cutting a Gordian knot: emended classification and description of the genus Flavobacterium, emended description of the family Flavobacteriaceae, and proposal of Flavobacterium hydatis nom. nov. (Basonym, Cytophaga aquatilis Strohl and Tait 1978). Int J Syst Bacteriol 46:128-148

Bertolini JM, Wakabayashi $H$, Watral VG, Whipple MJ,
Rohovec JS (1994) Electrophoretic detection of proteases from selected strains of Flexibacter psychrophilus and assessment of their variability. J Aquat Anim Health 6 : $224-233$

Bullock GL (1972) Studies on selected myxobacteria pathogenic for fishes and on bacterial gill disease in hatcheryreared salmonids. US Bur Sport Fish Wildl Tech Pap no. 60, Washington, DC

Chakroun C, Urdaci M, Faure D, Grimont F, Bernardet JF (1997) Random Amplified Polymorphic DNA analysis provides rapid differentiation among isolates of the fish pathogen Flavobacterium psychrophilum and between Flavobacterium species. Dis Aquat Org 31:187-196

Cipriano RC, Schill WB, Teska JD, Ford LA (1996) Epizootiological study of bacterial cold-water disease in Pacific salmon and further characterization of the etiologic agent, Flexibacter psychrophila. J Aquat Anim Health 8: $28-36$

Dalsgaard I (1993) Virulence mechanusms in Cytophaga psychrophila and other Cytophaga-like bacteria pathogenic for fish. In: Faisal M, Hetrick FM (eds) Annual review of fish diseases. Pergamon Press, New York, p 127-144

Grimont F, Grimont PAD (1986) Ribosomal ribonucleic acid gene restriction patterns as potential taxonomic tools. Ann Inst Pasteur Microbiol 1378:165-175

Grimont $F_{1}$ Grimont PAD (1995) Determination of rRNA gene restriction patterns. In: Howard J, Whitcombe DM (eds) Methods in molecular biology, Vol. 46, Diagnostic bacteriology protocols. Humana Press Inc, Totowa, NJ, p 181-200

Hänninen ML, Ridell J, Hirvelä-Koski V (1995) Phenotypic and molecular characteristics of Aeromonas salmonicida subsp. salmonicida isolated in Southern and Northern Finland. J Appl Bacteriol 79:12-21

Høi L, Dalsgaard A, Larsen JL, Warner JM, Olivier JD (1997) Comparison of ribotyping and randomly amplified polymorphic DNA PCR for characterization of Vibrio vulnifiCUS. Appl Environ Microbiol 63:1674-1678

Holt RA (1987) Cytophaga psychrophila, the causative agent of bacterial cold-water disease in salmonid fish. PhD thesis, Oregon State University, Corvallis, Oregon

Lorenzen E (1994) Studies on Flexibacter psychrophilus in relation to Rainbow Trout Fry Syndrome (RTFS). PhD thesis, Royal Veterinary and Agricultural University, Copenhagen, Denmark

Maniatis T, Fritch EF, Sambrook J (1982) Molecular cloning: a laboratory manual. Cold Spring Harbor Laboratories, Cold Spring Harbor, New York

Nielsen B, Olsen JE, Larsen JL (1994) Ribotyping of Aeromonas salmonicida subsp. salmonicida. Dis Aquat Org 18: $155-158$

Pacha RE (1968) Characteristics of Cytophaga psychrophila (Borg) isolated during outbreaks of bacterial coldwater disease. Appl Microbiol 16:97-101

Pazos F, Santos Y, Bandin I, Silva A, Toranzo AE (1993) Taxonomical and serological characteristics of Flexibacter spp. isolated from fish and freshwater. In: Book of Abstracts of the Sixth International Conference of the European Assoclation of Fish Pathologists. Centre National d'Etudes Vétérinaires et Alimentaires, Plouzané, p 11

Pedersen K, Larsen JL (1993) rRNA gene restriction patterns of Vibrio anguillarum serogroup O1. Dis Aquat Org 16: $121-126$

Pedersen K, Larsen JL (1995) Evidence for the existence of distinct populations of Vibrio anguillarum serogroup 01 based on plasmid contents and ribotypes. Appl Environ Microbiol 61:2292-2296 
Regnault B, Grimont F, Grimont PAD (1997) Universal ribotyping method using a chemically labelled oligonucleotide probe mixture. Res Microbiol 148:649-659

Schaffer HE, Sederoff RR (1981) Improved estimation of DNA fragment lengths from agarose gels. Anal Biochem 115: $113-122$

Schmidtke LM, Carson J (1995) Characteristics of Flexibacter psychrophilus isolated from Atlantic salmon in Australia. Dis Aquat Org 21:157-161

Editorial responsibility: Larry Vaughan, Dublin, Ireland
Takahashi S, Nagano Y (1984) Rapid procedure for isolation of plasmid DNA and application to epidemiological analysis. J Clin Microbiol 20:608-613

Tiainen T, Pedersen K, Larsen JL (1995) Ribotyping and plasmid profiling of Vibrio anguillarum serovar $\mathrm{O} 2$ and Vibrio ordalii. J Appl Bacteriol 79:384-392

Wakabayashi H, Toyama T, Iida T (1994) A study on serotyping of Cytophaga psychrophila isolated from fishes in Japan. Fish Pathol 29:101-104

Submitted: January 29, 1998; Accepted: May 5, 1998 Proofs received from author(s): July 14, 1998 